\title{
5. SEDIMENTS OF THE HAWAIIAN ARCH: X-RAY MINERALOGY AND MICROFABRIC ${ }^{1}$
}

\author{
Jane S. Tribble, ${ }^{2}$ Roy Wilkens, ${ }^{3}$ Rolf S. Arvidson, ${ }^{2}$ and Christopher J. Busing ${ }^{2}$
}

\begin{abstract}
The mineralogy of both bulk- and clay-sized $(<2 \mu \mathrm{m})$ fractions of sediments from Holes 842A and 842B of Ocean Drilling Program Leg 136 was determined by X-ray diffraction. The sediments consist of a combination of terrigenous (quartz, plagioclase, smectite, illite, kaolinite, and chlorite), volcaniclastic (augite, plagioclase, and volcanic glass), and diagenetic minerals (smectite, phillipsite, clinoptilolite, and opal-CT). Although biogenic silica (radiolarians and diatoms) is common in near-seafloor $(<10$ mbsf) sediments, biogenic calcite is rare. Variations with depth in abundances of the terrigenous minerals reflect temporal changes in the flux of eolian material to the site.

Volcanogenic material derived from the Hawaiian Islands is present in lithologic Unit 1 ( $0-19.9$ meters below seafloor) both as discrete layers and as finely disseminated silt- and clay-sized material. Volcanic glass is present only in the upper $10 \mathrm{~m}$ of the sediment column. In Unit 2 (19.9-35.7 mbsf), increased smectite and zeolite abundances with depth as well as indurated, zeolite-rich layers are thought to be the alteration products of volcanogenic material. The source of this older (late Oligocene to middle Miocene) volcanogenic detritus may be continental volcanism.

Microfabrics imaged using back-scattered electron imaging reflect the effects of compaction and diagenesis on sediment porosity and matrix structure. As porosity decreases during burial, the matrix changes from an open, floc-like fabric, to an interlocking network of clay mineral domains, and finally to a dense intergrowth of clay minerals and zeolites. Despite the substantial changes in sediment microfabric and mineralogy, correlations between physical and acoustic properties and mineralogy are weak or absent. The sediment has maintained high porosity $(>70 \%)$, and water content appears to dominate the sediment's physical character and acoustic response.
\end{abstract}

\section{INTRODUCTION}

During Leg 136 of the Ocean Drilling Program (ODP), samples were recovered from an area of the Pacific Ocean that has been little studied during past drilling expeditions. The only previous attempt to drill this region occurred during Deep Sea Drilling Project (DSDP) Leg 7 (Winterer, Riedel, et al., 1971) when Site 67 was drilled approximately $150 \mathrm{~km}$ north of Oahu. Three partial cores of badly disturbed, clay mineral- and volcaniclastic-rich sediment were recovered from $60 \mathrm{~m}$ of borehole before drilling was stopped because of difficulty in penetrating massive chert layers.

Sites 842 and 843 of Leg 136 are located approximately $225 \mathrm{~km}$ south-southwest of Oahu on the top of the large seafloor swell known as the Hawaiian Arch (Fig. 1). Geologic interest in the sites focused on (1) the analogy between the crust and overlying sediment and the material that floors the Hawaiian island and seamount chain and (2) the possibility of sampling a record of windborne volcanogenic sediments produced by the building of the Hawaiian Islands. At each site, drilling was severely hampered by chert intervals, which were encountered at extremely shallow depths ( $35 \mathrm{mbsf}$ ). Between $35 \mathrm{mbsf}$ and basaltic basement (approximately $235 \mathrm{mbsf}$ at Site 843 ) the only materials recovered were small hand-specimen-sized fragments of quartz chert. Because of time constraints, complete coring of the upper clay-rich sediments was carried out only at Site 842 . The following discussion will deal primarily with this site.

Clay-rich sediment recovered at Site 842 ranges from Quaternary to late Oligocene in age. Unit 1 (0-19.9 mbsf) consists of dark-brown silty clays, clayey silts, and clays, all with varying volcanic and biogenic (silica) components. Fresh glass is present in the uppermost sediments (less than about $10 \mathrm{mbsf}$ ) but is altered and disappears

'Wilkens, R.H., Firth, J., Bender, J., et al., 1993. Proc. ODP, Sci. Results, 136: College Station, TX (Ocean Drilling Program).

${ }^{2}$ Department of Oceanography, School of Ocean and Earth Science and Technology, University of Hawaii, Honolulu, HI 96822 , U.S.A.

${ }^{3}$ Hawaii Institute of Geophysics, School of Ocean and Earth Science and Technology, University of Hawaii, Honolulu, HI 96822, U.S.A. downcore. A color change to more reddish brown sediments and a decrease in silt content distinguishes Unit 2 from Unit 1 . Unit 2 (19.9-35.7 mbsf) consists of mid-Miocene to upper Oligocene zeolitic clays and claystones (some with opal-CT cement). An interesting feature of Unit 2 is the evidence of altered volcanogenic debris much deeper (and older) than was expected, given the relatively young age of the nearby Hawaiian Islands. The source of this volcanogenic material has yet to be identified, but it may be of continental derivation.

\section{METHODS \\ Bulk Mineralogy}

Bulk mineralogy was determined for 74 samples from Holes $842 \mathrm{~A}, 842 \mathrm{~B}, 842 \mathrm{C}$, and $843 \mathrm{~A}$ by $\mathrm{X}$-ray diffraction (XRD). Although a few layers of concentrated volcanogenic material were sampled, most of the samples were of the dominant background sediment. Samples were freeze-dried, powdered using an agate mortar and pestle or, if necessary, a Spex 8000 Mixer Mill, and packed into sample holders. Samples run aboard ship were scanned from $2^{\circ}$ to $60^{\circ}$ $2 \theta$, with a step size of $0.02^{\circ}$ and a counting time of $1 \mathrm{~s}$ per step. The shipboard Phillips ADP 3520 X-ray diffractometer used Ni-filtered $\mathrm{CuK} \alpha$ radiation with a tube voltage of $40 \mathrm{kV}$ and tube current of 35 $\mathrm{mA}$. The samples run on shore were continuously scanned from $2^{\circ}$ to $70^{\circ} 2 \theta$, using a chopper increment of $0.03^{\circ}$ and a scan speed of $1^{\circ}$ $2 \theta / \mathrm{min}$. The University of Hawaii (UH) Scintag PAD V X-ray diffractometer used unfiltered $\mathrm{CuK} \alpha$ radiation with a tube voltage of 45 $\mathrm{kV}$ and a tube current of $40 \mathrm{~mA}$.

The relative abundances of total clay minerals, quartz, plagioclase, calcite, augite, clinoptilolite, and phillipsite were estimated for the bulk samples from Hole $842 \mathrm{~A}$ and Hole $842 \mathrm{~B}$ through Sample 136-842B-4H-5, 94-96 cm (32.26 mbsf). Below this depth, abundant opal-CT interfered with the peaks necessary for the quantification program. The relative abundances of clay minerals, quartz, plagioclase, and calcite, normalized to $100 \%$, were estimated using a routine developed at UH. The routine was calibrated using nine different mixtures of the four phases prepared by combining commercially available standard minerals. 


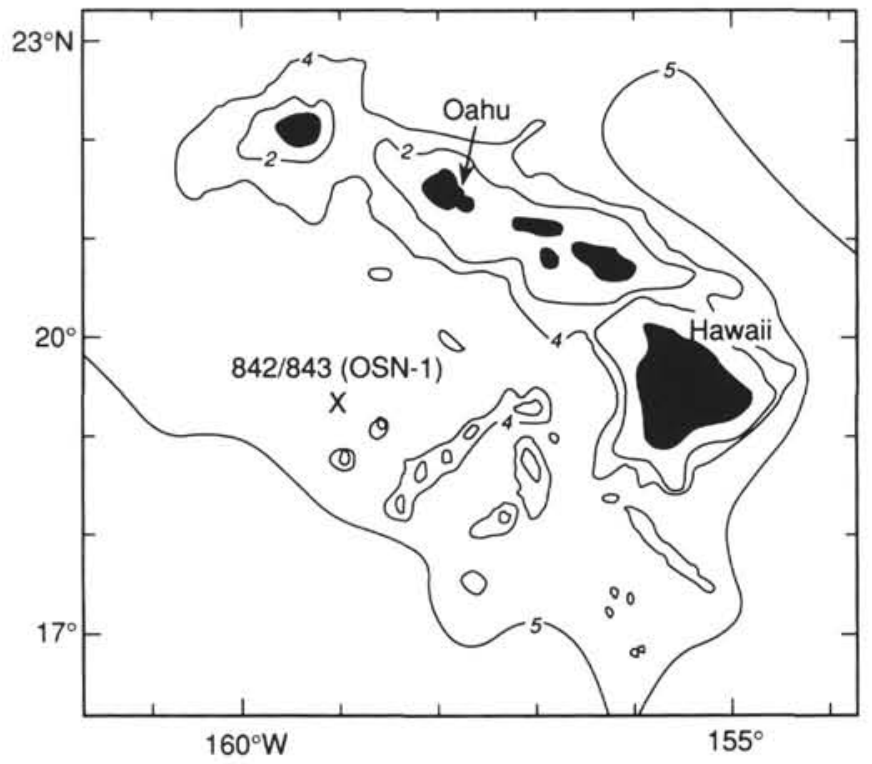

Figure 1. Location of Sites 842 and 843 . Bathymetry in kilometers.

Because of the importance of augite, clinoptilolite, and phillipsite in these sediments, an attempt was made to incorporate these phases in the quantification results. Weighting factors (WF) derived by Mann and Müller (1979) for quartz (WF $=1.3$ for $3.34 \AA$ peak), plagioclase (WF $=2.0$ for $3.18-3.25 \AA$ peak), augite $(\mathrm{WF}=2.0$ for $8.42 \AA$ peak), and clinoptilolite (WF $=2.0$ for $8.99 \AA$ peak) were multiplied by peak heights to obtain adjusted intensities. Mann and Müller (1979) did not publish a weighting factor for phillipsite, so a value of 2.0 for the $7.19 \AA$ peak was used (the mass absorption coefficient for phillipsite is similar to that for clinoptilolite). These results were normalized to $100 \%$, and the ratios to plagioclase of each of the minerals determined by the Mann and Müller (M\&M) method were calculated. The ratios of augite, clinoptilolite, and phillipsite to plagioclase were multiplied by the percentage of plagioclase determined by the UH routine, and the resulting combinations of the $\mathrm{UH}$ and $\mathrm{M} \& \mathrm{M}$ estimates were renormalized to $100 \%$.

Because the UH routine uses a minor quartz peak ( $4.26 \AA$ ) for quantification to avoid interferences, the quartz detection limit is higher than it is using the M\&M method. If the percentage of quartz was zero when determined by the $\mathrm{UH}$ routine and nonzero using the $\mathrm{M} \& \mathrm{M}$ method, the quartz/plagioclase ratio from the M\&M method was used to calculate the percentage of quartz rather than the $\mathrm{UH}$ routine.

\section{Clay Mineralogy}

On the basis of the bulk mineralogy, 26 samples were selected for mineralogical analysis of the clay-sized fraction. The $<2-\mu \mathrm{m}$ fraction was isolated by centrifugation after dispersal of the sediment in distilled water. Oriented mounts were prepared using either a vacuum filtration technique (Moore and Reynolds, 1989) or by pipetting onto a glass slide. Samples were air-dried and scanned from $2^{\circ}$ to $15^{\circ} 2 \theta$ at $1^{\circ} 2 \theta / \mathrm{min}$, and then saturated with ethylene glycol and scanned from $2^{\circ}$ to $28^{\circ} 2 \theta$ at $1^{\circ} 2 \theta / \mathrm{min}$ and from $59^{\circ}$ to $63^{\circ} 2 \theta$ at $0.25^{\circ} 2 \theta / \mathrm{min}$ using the Scintag instrument described previously.

Semiquantitative estimates of the relative abundances of smectite, illite, and the sum of kaolinite plus chlorite were based on peak areas determined using a Scintag profile-fitting routine. Methodologies and weighting factors (WF $=1$ for $17 \AA$ smectite peak; WF $=1.8$ for $7 \AA$ chlorite + kaolinite peak; WF $=8$ for $10 \AA$ illite peak) of Underwood et al. (1993) were used. Smectites in the near-seafloor $(<8 \mathrm{mbsf})$ sediments of both Holes $842 \mathrm{~A}$ and $842 \mathrm{~B}$ are poorly defined and peak areas were difficult to quantify. We believe, however, that the relative changes in smectite content are valid. The extent of mixed-layering in the smectite was estimated using shifts in positions of the $(001 / 002)$ and (002/003) peaks following Moore and Reynolds (1989), and the trioctahedral vs dioctahedral character of the smectite was evaluated from the position of the $(060)$ reflection.

\section{Scanning Electron Microscopy (SEM)}

Sixteen samples from Holes $842 \mathrm{~A}$ and $842 \mathrm{~B}$ were prepared for SEM, including two samples described as ash during shipboard examination. All samples were embedded in an ultra-low viscosity epoxy ( $n$-octenyl succinic anhydride, Ladd Industries) by initial immersion in acetone followed by gradual exchange of acetone for resin. This process permitted dehydration of the samples without destruction or alteration of delicate microfabric. After curing, sample plugs were micropolished and carbon sputter-coated.

All SEM was done on an ISI SS40 instrument equipped with a tungsten filament, secondary and backscatter electron detectors, and an energy dispersive (EDS) X-ray detector, using a $20 \mathrm{KeV}$ accelerating voltage. Routine examination (in backscatter mode) was made of all samples at magnifications of $200 \times, 500 \times, 1000 \times$, and $2000 \times$. Elemental composition of selected sites was also qualitatively analyzed using EDS for confirmation of compositional variation identified from backscatter imagery. This method supplied an important check on relative abundances of mineral components obtained from XRD data and was used to document the distribution of, and relationships among, terrigenous, matrix, and authigenic/diagenetic phases.

\section{RESULTS}

\section{Bulk Mineralogy}

The relative percentages of the major crystalline components of sediments from Holes $842 \mathrm{~A}$ and $842 \mathrm{~B}$, as well as several cherts from Hole $842 \mathrm{C}$ and two limestones from Hole $843 \mathrm{~A}$, are presented in Table 1. The discussion is limited to data from Holes $842 \mathrm{~A}$ and $842 \mathrm{~B}$ because they represent the most complete sections. In interpreting the $\mathrm{XRD}$ data, it is important to remember that noncrystalline components such as volcanic glass and biogenic silica, which may be common in some samples, were not quantified.

In general, the sediments are clay mineral-rich, containing roughly $70 \%-90 \%$ total clay minerals. Two volcanic silt/sand layers sampled in Unit 1 show no detectable clay mineral reflections on the XRD patterns. Overall, lithologic Unit 2 sediments are slightly more clay mineral-rich than those of Unit 1 (Fig. 2A), although sediments from depths of 8 to $18 \mathrm{mbsf}$ have somewhat lower percentages of total clay minerals than both shallower and deeper sediments (Fig. 2A).

Quartz content is low and tends to decrease with depth within lithologic Unit 1 from a maximum of $12 \%$ to less than $2 \%$ (Fig. $2 B$ ). At the top of Unit 2, a local maximum in quartz content occurs between 19 and 25 mbsf (Fig. 2B).

The plagioclase feldspar content of most sediments sampled from Unit 1 varies from $3 \%$ to $22 \%$ (Fig. 2C); exceptions include two volcanic silt/sand layers containing $65 \%$ and $88 \%$ plagioclase, respectively (Table 1). The Unit 1/Unit 2 boundary marks a drop in plagioclase content to values of less than $4 \%$ at the top of Unit 2. Plagioclase content within Unit 2 gradually increases with depth to a maximum of $10 \%$ at a depth of $25 \mathrm{mbsf}$ and then decreases gradually to values of $1 \%$ or $2 \%$ (Fig. $2 \mathrm{C}$ ).

Figure 2D shows the variation of augite content as a function of depth. In Unit 1, augite content is generally between $2 \%$ and $11 \%$, although one of the volcanic silt/sand layers sampled contains $31 \%$ augite. Augite percentages drop sharply at the Unit 1/Unit 2 boundary to values of less than $1 \%$.

Calcite content is generally zero. Exceptions include one sample from Hole $842 \mathrm{~A}$ ( $8.6 \mathrm{mbsf}$ ) and five samples from 13.4 to $18.4 \mathrm{mbsf}$ in Hole $842 \mathrm{~B}$, which contain up to $12 \%$ calcite (Table 1 ). 
Table 1. Bulk mineralogy of Site 842 and 843 sediments.

\begin{tabular}{|c|c|c|c|c|c|c|c|c|c|c|}
\hline $\begin{array}{l}\text { Core, section, } \\
\text { interval }(\mathrm{cm})\end{array}$ & $\begin{array}{l}\text { Depth } \\
\text { (mbsf) }\end{array}$ & $\begin{array}{l}\text { Total clay } \\
\text { minerals }\end{array}$ & Quartz & Plagioclase & Calcite & Augite & Clinoptiolite & Phillipsite & Opal-CT & $\begin{array}{c}\text { Amorphous } \\
\text { phases }\end{array}$ \\
\hline \multicolumn{11}{|l|}{$136-842 A-$} \\
\hline $1 \mathrm{H}-1,23$ & 0.23 & 74 & 4 & 12 & 0 & 10 & 0 & 0 & - & $\cdot$ \\
\hline $1 \mathrm{H}-1,35$ & 0.35 & 80 & 9 & 7 & 0 & 4 & 0 & 0 & - & - \\
\hline $1 \mathrm{H}-2,35$ & 1.85 & 86 & 6 & 6 & 0 & 2 & 0 & 0 & - & + \\
\hline $1 \mathrm{H}-2,145$ & 2.95 & 76 & 3 & 12 & 0 & 9 & 0 & 0 & $\cdot$ & ++ \\
\hline $1 \mathrm{H}-3,110$ & 4.10 & 83 & 5 & 6 & 0 & 5 & 0 & 0 & - & ++ \\
\hline $1 \mathrm{H}-4,110$ & 5.60 & 86 & 3 & 7 & 0 & 5 & 0 & 0 & - & ++ \\
\hline $1 \mathrm{H}-5,35$ & 6.35 & 85 & 4 & 7 & 0 & 4 & 0 & 0 & - & + \\
\hline $1 \mathrm{H}-5,145$ & 7.45 & 86 & 3 & 7 & 0 & 4 & 0 & 0 & - & - \\
\hline $1 \mathrm{H}-6,35$ & 7.85 & 82 & 4 & 9 & 0 & 5 & 0 & 0 & - & + \\
\hline $1 \mathrm{H}-6,63$ & 8.13 & 0 & 4 & 88 & 0 & 8 & 0 & 0 & - & - \\
\hline $1 \mathrm{H}-6,109$ & 8.59 & 71 & 2 & 10 & 9 & 8 & 0 & 0 & - & + \\
\hline $1 \mathrm{H}-7,6$ & 9.06 & 0 & 4 & 65 & 0 & 31 & 0 & 0 & - & + \\
\hline $1 \mathrm{H}-7,25$ & 9.25 & 81 & 4 & 9 & 0 & 6 & 0 & 0 & $\cdot$ & + \\
\hline \multicolumn{11}{|l|}{$136-842 B-$} \\
\hline $1 \mathrm{H}-1,110$ & 1.10 & 83 & 7 & 8 & 0 & 3 & 0 & 0 & - & . \\
\hline $1 \mathrm{H}-1,145$ & 1.45 & 84 & 7 & 5 & 0 & 4 & 0 & 0 & - & - \\
\hline $1 \mathrm{H}-2,110$ & 2.60 & 81 & 0 & 9 & 0 & 11 & 0 & 0 & - & ++ \\
\hline $1 \mathrm{H}-3,35$ & 3.35 & 86 & 4 & 6 & 0 & 4 & 0 & 0 & - & ++ \\
\hline $1 \mathrm{H}-3,145$ & 4.45 & 80 & 7 & 8 & 0 & 5 & 0 & 0 & - & + \\
\hline $1 \mathrm{H}-4,35$ & 4.85 & 83 & 8 & 5 & 0 & 4 & 0 & 0 & - & + \\
\hline $1 \mathrm{H}-4,110$ & 5.60 & 79 & 0 & 15 & 0 & 6 & 0 & 0 & - & $\cdot$ \\
\hline $1 \mathrm{H}-5,13$ & 6.13 & 84 & 6 & 6 & 0 & 4 & 0 & 0 & - & - \\
\hline $2 \mathrm{H}-1,110$ & 7.40 & 75 & 5 & 11 & 0 & 6 & 0 & 3 & - & - \\
\hline $2 \mathrm{H}-2,35$ & 8.15 & 68 & 4 & 22 & 0 & 4 & 0 & 2 & - & - \\
\hline $2 \mathrm{H}-2,110$ & 8.90 & 70 & 4 & 20 & 0 & 4 & 0 & 1 & - & - \\
\hline $2 \mathrm{H}-3,110$ & 10.40 & 81 & 0 & 10 & 0 & 6 & 0 & 2 & - & - \\
\hline $2 \mathrm{H}-3,145$ & 10.75 & 78 & 0 & 13 & 0 & 7 & 0 & 2 & - & - \\
\hline $2 \mathrm{H}-4,35$ & 11.15 & 73 & 5 & 12 & 0 & 6 & 0 & 4 & - & - \\
\hline $2 \mathrm{H}-4,110$ & 11.90 & 71 & 4 & 12 & 0 & 7 & 0 & 5 & - & - \\
\hline $2 \mathrm{H}-5,73$ & 13.03 & 80 & 0 & 17 & 0 & 0 & 0 & 3 & - & - \\
\hline $2 \mathrm{H}-5,77$ & 13.07 & 77 & 0 & 15 & 0 & 4 & 0 & 4 & - & - \\
\hline $2 \mathrm{H}-5,84$ & 13.14 & 77 & 0 & 16 & 0 & 4 & 0 & 3 & - & - \\
\hline $2 \mathrm{H}-5,90$ & 13.20 & 82 & 0 & 10 & 0 & 5 & 0 & 3 & - & - \\
\hline $2 \mathrm{H}-5,92$ & 13.22 & 80 & 0 & 11 & 0 & 5 & 0 & 4 & - & $\cdot$ \\
\hline $2 \mathrm{H}-5,110$ & 13.40 & 77 & 2 & 7 & 12 & 0 & 0 & 2 & - & - \\
\hline $2 \mathrm{H}-5,136$ & 13.66 & 79 & 6 & 4 & 0 & 8 & 0 & 3 & - & - \\
\hline $2 \mathrm{H}-5,145$ & 13.75 & 79 & 0 & 15 & 0 & 2 & 0 & 4 & - & - \\
\hline $2 \mathrm{H}-6,11$ & 13.91 & 80 & 3 & 5 & 8 & 2 & 0 & 2 & - & - \\
\hline $3 \mathrm{H}-1,26$ & 16.06 & 79 & 0 & 12 & 0 & 6 & 0 & 2 & - & - \\
\hline $3 \mathrm{H}-1,35$ & 16.15 & 71 & 0 & 10 & 9 & 7 & 0 & 3 & - & - \\
\hline $3 \mathrm{H}-1,110$ & 16.90 & 75 & 0 & 11 & 6 & 5 & 0 & 2 & - & - \\
\hline $3 \mathrm{H}-2,73$ & 18.03 & 75 & 0 & 14 & 0 & 9 & 0 & 2 & - & - \\
\hline $3 \mathrm{H}-2,110$ & 18.40 & 83 & 2 & 6 & 4 & 4 & 0 & 1 & - & - \\
\hline $3 \mathrm{H}-2,145$ & 18.75 & 78 & 0 & 9 & 0 & 11 & 0 & 2 & - & - \\
\hline $3 \mathrm{H}-3,35$ & 19.15 & 83 & 7 & 6 & 0 & 2 & 0 & 2 & - & - \\
\hline $3 \mathrm{H}-3,110$ & 19.90 & 84 & 6 & 6 & 0 & 1 & 0 & 3 & - & - \\
\hline $3 \mathrm{H}-4,110$ & 21.40 & 83 & 9 & 2 & 0 & 1 & 1 & 4 & - & - \\
\hline $3 \mathrm{H}-5,145$ & 23.25 & 90 & 8 & 1 & 0 & 0 & 0 & 1 & - & - \\
\hline $3 \mathrm{H}-6,35$ & 23.65 & 89 & 7 & 2 & 0 & 0 & 0 & 2 & - & - \\
\hline $3 \mathrm{H}-6,105$ & 24.35 & 89 & 6 & 3 & 0 & 0 & 0 & 1 & - & - \\
\hline $3 \mathrm{H}-6,110$ & 24.40 & 84 & 8 & 4 & 0 & 0 & 0 & 3 & - & - \\
\hline $3 \mathrm{H}-7,49$ & 25.29 & 76 & 3 & 10 & 0 & 0 & 1 & 10 & - & - \\
\hline $4 \mathrm{H}-1,110$ & 26.40 & 84 & 3 & 6 & 0 & 0 & 1 & 6 & - & - \\
\hline $4 \mathrm{H}-2,110$ & 27.90 & 83 & 5 & 5 & 0 & 0 & 4 & 4 & - & - \\
\hline $4 \mathrm{H}-2,145$ & 28.25 & 87 & 4 & 5 & 0 & 1 & 0 & 3 & - & - \\
\hline $4 \mathrm{H}-3,35$ & 28.65 & 88 & 5 & 3 & 0 & 1 & 1 & 3 & - & - \\
\hline $4 \mathrm{H}-3,110$ & 29.40 & 86 & 5 & 2 & 0 & 1 & 2 & 5 & - & - \\
\hline $4 \mathrm{H}-4,35$ & 30.15 & 88 & 5 & 2 & 0 & 1 & 2 & 2 & - & - \\
\hline $4 \mathrm{H}-4,110$ & 30.90 & 90 & 4 & 3 & 0 & 0 & 1 & 2 & - & - \\
\hline $4 \mathrm{H}-5,35$ & 31.65 & 93 & 4 & 2 & 0 & 0 & 1 & 0 & + & - \\
\hline $4 \mathrm{H}-5,94$ & 32.24 & 91 & 6 & 1 & 0 & 1 & 1 & 0 & + & - \\
\hline $4 \mathrm{H}-5,98$ & 32.28 & ++ & + & + & . & - & + & - & ++ & - \\
\hline $4 \mathrm{H}-5,145$ & 32.75 & ++ & + & + & - & - & + & - & ++ & - \\
\hline $4 \mathrm{H}-6,8$ & 32.88 & + & + & + & - & - & . & - & ++ & - \\
\hline $5 \mathrm{H}-1,26$ & 35.06 & + & + & - & - & - & - & - & ++ & - \\
\hline $6 \mathrm{X}-\mathrm{CC}, 6$ & 35.76 & ++ & + & - & - & - & - & - & ++ & - \\
\hline $7 \mathrm{X}-\mathrm{CC}, 7$ & 39.27 & + & + & - & . & - & . & - & ++ & - \\
\hline $8 \mathrm{X}-\mathrm{CC}, 9$ & 48.79 & + & + & - & - & - & - & - & ++ & - \\
\hline \multicolumn{11}{|l|}{$136-842 \mathrm{C}-$} \\
\hline 1W-1,3 & 141.33 & 52 & 48 & 0 & 0 & 0 & 0 & 0 & - & - \\
\hline $1 W-1,8$ & 141,38 & 32 & 54 & 0 & 15 & 0 & 0 & 0 & - & - \\
\hline $1 \mathrm{~W}-1,38$ & 141.68 & 34 & 61 & 0 & 5 & 0 & 0 & 0 & - & - \\
\hline $1 \mathrm{~W}-1,72$ & 142.02 & 0 & 94 & 0 & 6 & 0 & 0 & 0 & - & - \\
\hline $1 \mathrm{~W}-1,95$ & 142.25 & 0 & 91 & 0 & 9 & 0 & 0 & 0 & . & - \\
\hline \multicolumn{11}{|l|}{$136-843 A-$} \\
\hline $3 R-1,20$ & 228.20 & 0 & 0 & 0 & 100 & 0 & 0 & 0 & - & - \\
\hline $3 R-1,77$ & 228.77 & 14 & 1 & 0 & 85 & 0 & 0 & 0 & - & - \\
\hline
\end{tabular}

Notes: Semiquantitative estimates of mineral abundances are given in weight percentages. When quantification was not possible, the presence of a mineral is indicated as follows: $++=$ abundant: $+=$ minor component; - = absent. The term "amorphous phases" refers to biogenic silica and/or volcanic glass. 

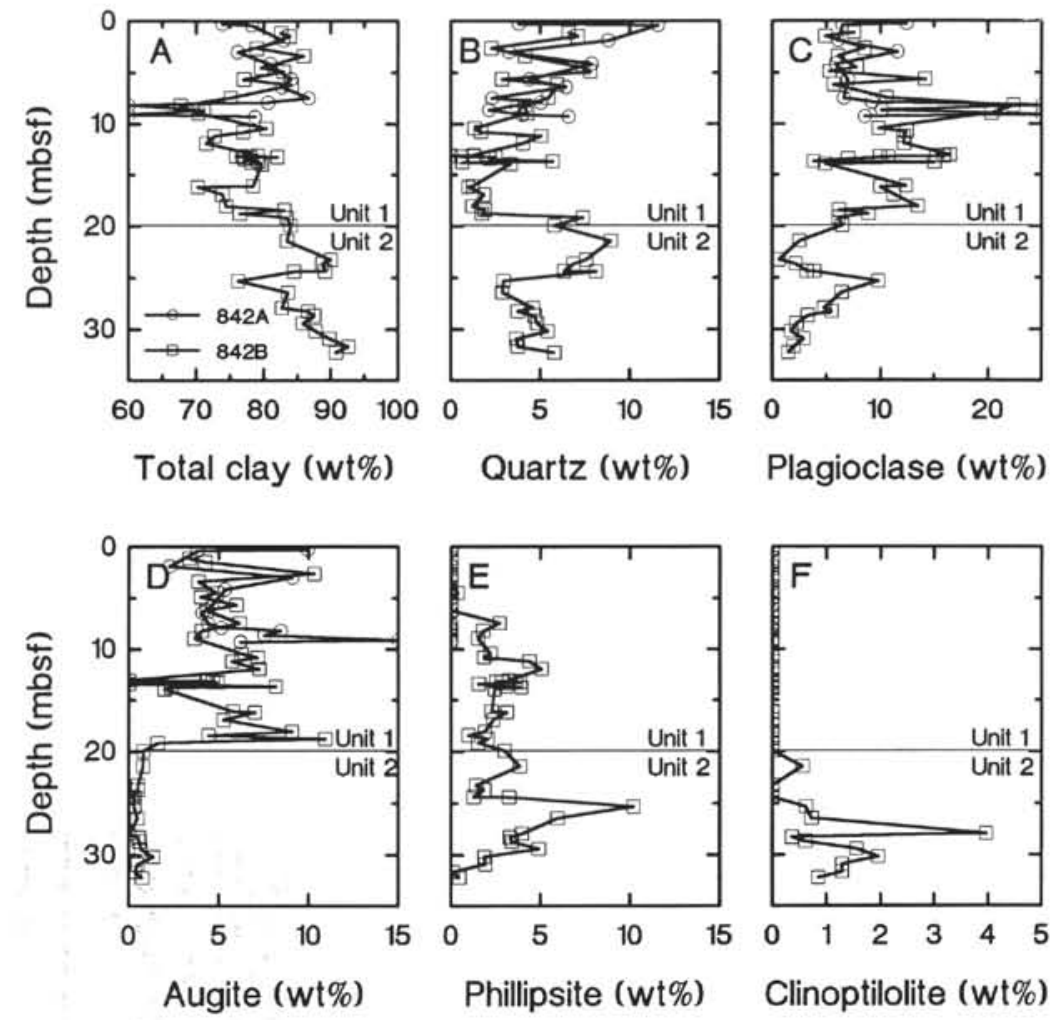

Figure 2. Mineralogy as a function of depth for the bulk sediments from Holes $842 \mathrm{~A}$ and $842 \mathrm{~B}$. The Unit $1 /$ Unit 2 boundary for Hole $842 \mathrm{~B}$ is indicated. A. Total clay minerals. Half circles between 8 and $10 \mathrm{mbsf}$ indicate data points from two ash layers that plot off the scale of the graph. Actual values for these data points can be found in Table 1. B. Quartz. C. Plagioclase. Half circles are as in Figure 2A. D. Augite. The half circle at $\sim 9$ mbsf is as in Figure 2A. E. Phillipsite. F. Clinoptilolite.

Phillipsite is absent from Hole $842 \mathrm{~A}$ and does not appear above a depth of 5 mbsf in Hole 842B (Fig. 2E and Table 1). Its abundance varies between $1 \%$ and $5 \%$ throughout Unit 1 , increases to a maximum of $10 \%$ at 25.3 mbsf in Unit 2, and then decreases with depth. Phillipsite was not detected below a depth of $31 \mathrm{mbsf}$.

Clinoptilolite is not present in Unit 1 sediments of either Hole $842 \mathrm{~A}$ or Hole $842 \mathrm{~B}$. Clinoptilolite first appears at a depth of $21.4 \mathrm{mbsf}$ in Hole $842 \mathrm{~B}$, increases to a maximum of $4 \%$ at $27.9 \mathrm{mbsf}$, and then decreases with depth (Fig. 2F). Clinoptilolite was not observed below a depth of 32.3 mbsf.

Opal-CT becomes an important constituent of the sediments at depths greater than 32.24 mbsf in Hole 842B (Table 1). These highly indurated sediments contain opal-CT, clay minerals, and minor quartz, plagioclase, and clinoptilolite. No attempt was made to quantify the $\mathrm{XRD}$ results for opal-CT-bearing samples.

\section{Clay Mineralogy}

The relative abundances of the clay minerals smectite, illite, and kaolinite plus chlorite $(\mathrm{K}+\mathrm{C})$ are given in Table 2 . The presence of additional phases such as quartz, plagioclase, phillipsite, clinoptilolite, and XRD amorphous volcanic glass and biogenic silica are also indicated in Table 2.

Figure 3 is a plot of cumulative weight percent vs. depth for the clay minerals. There is a large overall increase in the percentage of smectite from $6 \%$ in the shallowest sample to greater than $90 \%$ at depth. Smectite also appears to increase in crystallinity with depth. Near-seafloor sediments ( $<8 \mathrm{mbsf})$ have poorly defined, broad smectite peaks, whereas in samples from greater burial depths, the smectite peaks are sharp and well defined (Fig. 4). Because of the poorly defined nature of the smectite peaks in many samples, attempts to determine the extent of mixed-layering or the dioctahedral vs. trioctahedral character of the smectite met with mixed success. Estimates of the extent of interlayering for 14 samples show no apparent trend with depth; Unit 1 smectites contain from $0 \%$ to $40 \%$ illite interlayers with an average of $20 \%$, whereas Unit 2 smectites contain from $0 \%$ to $35 \%$ illite interlayers with an average of $15 \%$. The d-spacings of the $(060)$ diffraction peaks of these smectites fall in the range 1.505 to $1.509 \AA$ indicating primarily dioctahedral character.

The weight percentage of illite decreases with depth from a maximum of $76 \%$ to a minimum of $5 \%$ (Fig. 3). The decline in illite content is relatively continuous to a depth of 16 mbsf. Between 19 and $24 \mathrm{mbsf}$ there is a distinct local maximum in illite content followed by a decrease to $5 \%$ illite in the deepest sample analyzed (29.4 mbsf).

The $\mathrm{K}+\mathrm{C}$ content decreases slightly with depth, although three samples between 11 and 14 mbsf form a distinct maximum (Fig. 3). A major peak for phillipsite interferes with the peak used for quantification of K + C. Samples 136-842B-2H-4, 35-37 cm, 136-842B$2 \mathrm{H}-4,110-112 \mathrm{~cm}$, and $136-842 \mathrm{~B}-2 \mathrm{H}-6,11-13 \mathrm{~cm}$, all contain significant amounts of phillipsite, which probably accounts for the anomalously high estimates of $\mathrm{K}+\mathrm{C}$ abundance for these three samples (Table 2). We believe the interference from phillipsite is negligible in the rest of the samples.

In addition to clay minerals, quartz and plagioclase are also present in the clay-size fraction of most samples (Table 2). Phillipsite first appears in the clay-size fraction at a depth of 7.4 mbsf in Hole 842B and disappears at depths greater than 16.9 mbsf. Clinoptilolite is 


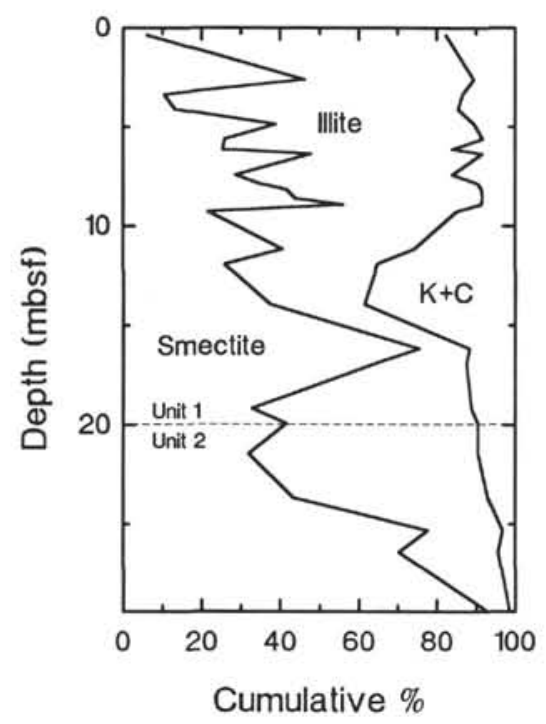

Figure 3. Plot of smectite, illite, and kaolinite plus chlorite in the clay-sized fraction as a function of depth.

present in samples from burial depths $\geq 19.9$ mbsf. The broad diffractions resulting from X-ray amorphous phases (volcanic glass and/or biogenic silica) are largest in the near-seafloor samples and disappear over the depth range of 7-9 mbsf (Table 2).

\section{Sediment Microfabric}

Observations of sediment microfabric were made using back-scattered electron imaging (BSEI), which distinguishes between sources of X-ray amorphous phases and reveals changes in the nature and distribution of porosity with depth. This method also permits assessment of the importance of diagenetic reactions in the alteration of the physical character and chemical composition of the sediment. These observations are discussed in order of appearance by increasing depth. For reference, the location of each BSEI sample is indicated on a plot of shipboard porosity vs. depth (Fig. 5).

The shallowest samples examined have porosities of about $90 \%$ (Fig. 5). The sediment matrix is made up of aggregates of finegrained, floc-like clay minerals (Pl. 1, Figs. 1, 2). These aggregates, generally $20-100 \mu \mathrm{m}$ in diameter, are interspersed with pore spaces of similar dimensions. The aggregates of clay minerals must also have substantial amounts of intergranular porosity. Silt-sized quartz, plagioclase, and augite, and silt- and sand-sized radiolarians and diatom spines are dispersed throughout the sediment.

Volcanic glass was observed in two samples examined by BSEI (136-842A-1H-2, 143-145 cm, and 136-842A-1H-5, 143-145 cm). Plate 1, Figure 3, shows typical silt-sized glass shards. The edges of the shards are generally clean, although in some shards incipient alteration is apparent. The sand-sized shard in Plate 1, Figure 4, has a cloudy appearance and contains crystals of higher density than the glass; these features are indicative of incipient crystallization during quenching.

Initial dissolution of radiolarians is evident at burial depths of $<2$ mbsf, and subsequent, nearly complete dissolution of the tests created large voids in somewhat deeper sections (>7 mbsf; Pl. 2, Fig. 1). Despite these large pores, overall porosity is somewhat lower at this depth (Fig. 5), presumably because of reduced matrix porosity. Long, porous rods, a few microns in diameter and up to $140 \mu \mathrm{m}$ in length, tentatively identified as diatom spines (D. Hull, pers. comm., 1992), appear to be less susceptible to dissolution than the radiolarians (Pl. 2, Fig. 2).

The nature of porosity and the matrix change as the sediments are buried more deeply (>10 mbsf). Porosities are still high $(\sim 85 \%$;

Table 2. Mineralogy of the $<2-\mu \mathrm{m}$ clay-sized fraction of Site 842 sediments.

\begin{tabular}{|c|c|c|c|c|c|c|c|c|c|}
\hline $\begin{array}{l}\text { Core, section, } \\
\text { interval }(\mathrm{cm})\end{array}$ & $\begin{array}{l}\text { Depth } \\
\text { (mbsf) }\end{array}$ & Smectite & Illite & $\begin{array}{l}\text { Kaolinite } \\
\text { + chlorite }\end{array}$ & Quartz & Plagioclase & Phillipsite & Clinoptilolite & $\begin{array}{c}\text { Amorphous } \\
\text { phases }\end{array}$ \\
\hline & & & & & & & & & \\
\hline $136-842 A-$ & & & & & & & & & \\
\hline $1 \mathrm{H}-1,35$ & 0.35 & 6 & 76 & 18 & ++ & ++ & - & - & - \\
\hline $1 \mathrm{H}-3,110$ & 4.10 & 13 & 72 & 15 & ++ & + & - & $\cdot$ & + \\
\hline $1 \mathrm{H}-4,110$ & 5.60 & 26 & 66 & 8 & ++ & + & - & - & + \\
\hline $1 \mathrm{H}-5,35$ & 6.35 & 48 & 44 & 8 & ++ & + & - & - & + \\
\hline $1 \mathrm{H}-6,35$ & 7.85 & 35 & 56 & 10 & ++ & ++ & - & . & + \\
\hline $1 \mathrm{H}-6,109$ & 8.59 & 44 & 48 & 8 & ++ & ++ & - & . & - \\
\hline $1 H-7,25$ & 9.25 & 22 & 63 & 15 & ++ & ++ & - & - & + \\
\hline \multicolumn{10}{|l|}{$136-842 B$} \\
\hline $1 \mathrm{H}-2,110$ & 2.60 & 46 & 43 & 11 & + & + & - & - & + \\
\hline $1 \mathrm{H}-3,35$ & 3.35 & 10 & 76 & 13 & ++ & + & - & - & + \\
\hline $1 \mathrm{H}-4,35$ & 4.85 & 39 & 51 & 10 & ++ & + & - & . & + \\
\hline $1 \mathrm{H}-5,13$ & 6.13 & 25 & 59 & 16 & ++ & + & - & . & + \\
\hline $2 \mathrm{H}-1,110$ & 7.40 & 29 & 55 & 16 & ++ & ++ & + & - & . \\
\hline $2 \mathrm{H}-2,35$ & 8.15 & 42 & 50 & 9 & ++ & + & . & . & - \\
\hline $2 \mathrm{H}-2,110$ & 8.90 & 56 & 35 & 9 & ++ & + & - & - & . \\
\hline $2 \mathrm{H}-4,35$ & 11.15 & 41 & 34 & 26 & + & + & ++ & - & - \\
\hline $2 \mathrm{H}-4,110$ & 11.90 & 26 & 39 & 35 & + & + & ++ & . & - \\
\hline $2 \mathrm{H}-6,11$ & 13.91 & 37 & 24 & 39 & + & - & ++ & - & . \\
\hline $3 \mathrm{H}-1,35$ & 16.15 & 75 & 13 & 12 & + & + & + & . & - \\
\hline $3 \mathrm{H}-1,110$ & 16.90 & 64 & 24 & 12 & + & + & + & - & . \\
\hline $3 \mathrm{H}-3,35$ & 19.15 & 33 & 56 & 11 & ++ & + & - & - & . \\
\hline $3 \mathrm{H}-3,110$ & 19.90 & 41 & 49 & 10 & + & . & - & + & - \\
\hline $3 \mathrm{H}-4,110$ & 21.40 & 32 & 59 & 10 & ++ & . & . & + & - \\
\hline $3 \mathrm{H}-6,35$ & 23.65 & 43 & 50 & 7 & ++ & + & . & + & . \\
\hline $3 \mathrm{H}-7,49$ & 25.29 & 78 & 19 & 3 & + & - & - & + & - \\
\hline $4 \mathrm{H}-1,110$ & 26.40 & 70 & 25 & 4 & ++ & + & - & + & - \\
\hline $4 \mathrm{H} \cdot 3,110$ & 29.40 & 93 & 5 & 1 & + & + & . & + & . \\
\hline
\end{tabular}

Notes: Semiquantitative estimates of mineral abundances are given in weight percentages and are summed to $100 \%$ for the clay minerals. Presence of other minerals is indicated as follows: $++=$ abundant, $+=$ minor component, $-=$ absent. The term "amorphous phases" refers to biogenic silica and/or volcanic glass. 


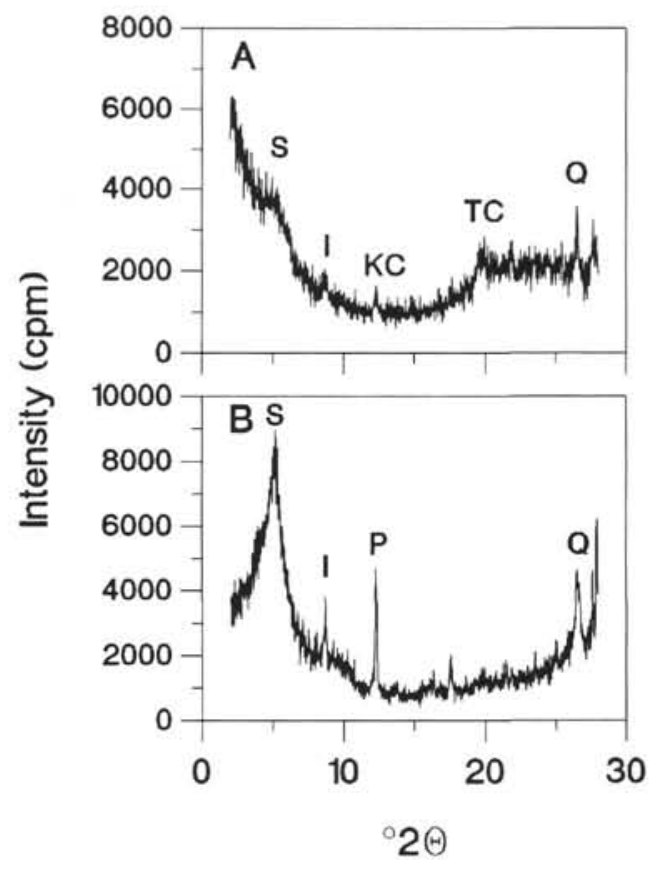

Figure 4. X-ray-diffraction patterns of the clay-sized fraction of samples from Site $842 . \mathrm{S}=$ smectite, $\mathrm{I}=$ illite, $\mathrm{KC}=$ undifferentiated kaolinite and chlorite, $\mathrm{P}=$ phillipsite, $\mathrm{TC}=$ total undifferentiated clay minerals, and $\mathrm{Q}=$ quartz. $\mathbf{A}$. The smectite peak is poorly defined in this shallowly buried sample (136$842 \mathrm{~A}-1 \mathrm{H}-4,110-112 \mathrm{~cm}$ ). The increase in background above $20^{\circ} 2 \theta$ reflects scattering from amorphous silica and volcanic glass. B. In this stratigraphically deeper sample (136-842B-3H-1, 110-112 cm), the smectite peak is sharper and better defined, reflecting increased crystallinity, or increased grain size.

Fig. 5), but pore spaces visible at SEM scale are generally smaller than in shallower sediments $(\sim 2-10 \mu \mathrm{m}$; Pl. 2, Fig. 3). The clay minerals in the matrix have lost their floc-like appearance (compare Pl. 1, Figs. 1, 2) and instead form an interlocking network of clay domains (Pl. 2, Figs. 3, 4). Silt-sized quartz, plagioclase, augite, and phillipsite are dispersed throughout the sediment.

A sediment described as an ash layer by shipboard scientists was examined by BSEI (Sample 136-842B-2H-5, 142-145 cm). The microfabric is characterized by a dense clay mineral and zeolite matrix with numerous large voids up to $150 \mu \mathrm{m}$ in their longest dimension (Pl. 3, Figs. 1, 2). The voids generally have smooth, sharp contacts with the matrix, although some growth of phillipsite into and within the voids was observed. The matrix is a dense intergrowth of phillipsite and clay minerals with irregularly shaped, poorly defined pore spaces (Pl. 3, Fig. 2). This microfabric is unlike that observed in any of the surrounding, nonvolcanogenic sediments and appears to be somewhat lower in porosity.

The reduction in porosity below approximately $16 \mathrm{mbsf}$ (Fig. 5) is probably due to compaction of the matrix as well as infilling of pore space by growth of zeolites. In Plate 3, Figure 3, the interlocking network of clay domains is still evident, but the matrix porosity has decreased (compare Pl. 2, Figs. 3, 4). Zeolites are present both as individual grains and as clusters.

Further burial resulted in additional compaction of the matrix, and the network of clay domains characteristic of shallower samples is no longer apparent (Pl. 3, Fig. 4). The matrix appears dense and pore spaces are a few microns or less in diameter. Porosities, however, are still about $80 \%$ (Fig. 5). Silt-sized quartz, plagioclase, and phillipsite are dispersed throughout the sample.

Abundant growth of phillipsite and clinoptilolite was observed at depths greater than about 25 mbsf (Pl. 4, Fig. 1). The matrix has an appearance similar to the interlocking network seen in shallower

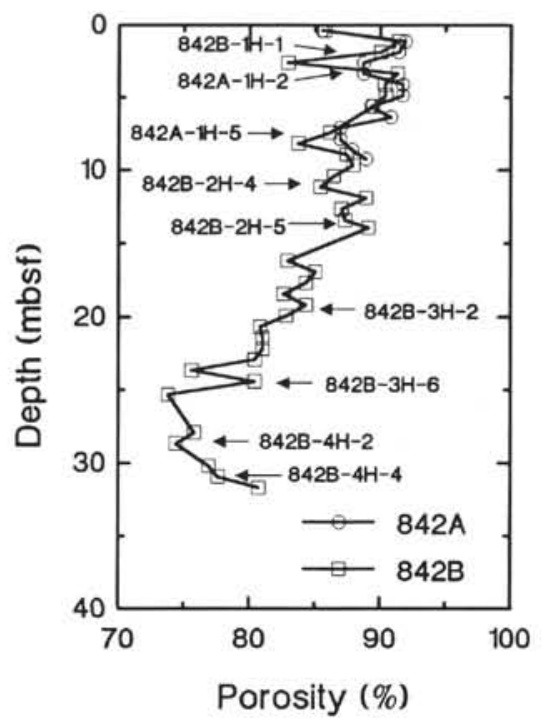

Figure 5. Variation of porosity as a function of depth at Site 842. Data are from Shipboard Scientific Party (1992), Depth locations of samples analyzed by BSEI are indicated by arrows and the appropriate sample identifier. The porosity measurements were not made on the same samples as the BSEI analyses.

sediments (compare Pl. 2, Fig. 4, and Pl. 3, Fig. 3), although it is more dense. Zeolites crystallized in the pore spaces within the clay domain network, but rarely filled them. At a depth of about $31 \mathrm{mbsf}$, the matrix retains the network-like appearance, but the size and abundance of zeolites has decreased somewhat (Pl. 4, Fig. 2). Many grains, tentatively identified as phillipsite from EDS spectra, show evidence of dissolution (Pl. 4, Fig. 3).

\section{DISCUSSION}

The sediments at Site 842 represent a mixture of detrital and diagenetic components. The minerals common in pelagic clay provinces dominate the mineralogy of the bulk and clay-sized fractions: smectite, illite, kaolinite, chlorite, biogenic silica, quartz, and plagioclase. Calcite is rare because the site is below the carbonate compensation depth (CCD). The relative proportions of detrital components at Site 842 are similar to those in North Pacific pelagic clay sampled at Sites 576, 578, and 581 of DSDP Leg 86 (Heath, Burckle, et al., 1985). Twenty-nine samples of pelagic clay from the Leg 86 sites have the following mean composition: $78 \%$ total clay minerals, $15 \%$ quartz, and 7\% plagioclase (Schoonmaker et al., 1985). In comparison, Site 842 sediments contain an average of $78 \%$ total clay minerals, $4 \%$ quartz, and $10 \%$ plagioclase (Table 1 ). The difference in quartz content probably reflects eolian fluxes as discussed below.

The depth variations of detrital components result in part from changes in sediment sources as a function of time. Plate movement has carried Site 842 to the northwest from its origin on the East Pacific Rise. The sediment section studied here represents approximately the last 30 m.y., during which time Site 842 traveled from just north of the equator to its present location. This transit brought Site 842 through the zone of the northeast trade winds and closer to the belt of the Northern Hemisphere westerlies and the Hawaiian Islands. Studies of eolian sedimentation in cores from the North Pacific (Leinen and Heath, 1981; Janecek, 1985; Leinen, 1985) documented increased rates of eolian deposition as the core sites moved through the zone of the westerlies. The onset of Northern Hemisphere glaciation at about $2.5 \mathrm{Ma}$ is also cited by these studies as a reason for increased eolian deposition in the sediments. The depth profiles of quartz and illite contents (Figs. 2B and 3) illustrate a similar influence of eolian sedimentation at Site 842. Paleomagnetic dating (Shipboard Scien- 
tific Party, 1992) indicates an age of 2.48 Ma at a depth of $12-13 \mathrm{mbsf}$ in Hole 842 B. Illite increases dramatically from values near $20 \%$ of the clay-size fraction at about 14 mbsf to nearly $80 \%$ at less than 1 mbsf (Fig. 3). Quartz content of the bulk sediment also increases substantially over this depth range (Fig. 2B). It is likely that both the onset of glaciation and the increased proximity of the site to the zone of the westerlies are responsible for these increases.

In addition to the mineralogic trends in lithologic Unit 1, local maxima in both quartz and illite contents are present in lithologic Unit 2 sediments between 19 and 25 mbsf (Figs. 2B and 3). These sediments have been dated as early to middle Miocene using ichthyolith stratigraphy (Firth and Hull, this volume). Increased percentages of quartz were noted by Leinen (1985) in Miocene sediments from DSDP Hole 576A (from 18 m.y. ago) and central North Pacific core LL44-GPC3 (from 23 m.y. ago). It was suggested that the increased accumulation of quartz reflected movement of these two sites into the zone of the westerlies. Uncertainties in the stratigraphy of the two northern sites studied by Leinen (1985) and the lack of detailed stratigraphy for Site 842 make comparisons tenuous, but the approximate temporal coincidence of the increased quartz content at the two northern sites and Site 842 , which are separated by $13^{\circ}$ of latitude, supports the suggestion made by Janecek (1985) that an increase in global aridity resulting from expansion of ice in Antarctica magnified eolian depositional rates at that time.

Site 842 has also received significant amounts of volcanogenic detritus from the Hawaiian Islands group. Plagioclase, augite, and volcanic glass are major constituents of the volcanogenic fraction. Although olivine was noted in thin-section studies of these sediments (Garcia, this volume), it was not positively identified by XRD. Numerous layers of concentrated volcanogenic detritus were identified in Unit 1 by the shipboard scientists (Shipboard Scientific Party, 1992). Although originally thought to be ash layers, Garcia (this volume) and Naka et al. (this volume) interpreted the layers in the upper $14 \mathrm{~m}$ of section to be turbidites generated by landslides along the flanks of the Hawaiian Islands chain. Evidence of this origin includes glass shard morphology (Garcia, this volume) and the presence of reworked Eocene radiolarians in the layers dominated by volcanogenic debris (Hull, this volume). The reworked fauna are absent from the bulk sediment. At depths greater than $14 \mathrm{mbsf}$, indurated layers of zeolitic clay are thought to be volcanogenic layers that are nearly completely altered.

In addition to these volcanogenic debris-rich layers, volcanogenic detritus is present as yellowish brown blebs and stringers of ash and as finely disseminated material throughout the Unit 1 sediments. Augite, an indicator of volcanic input to the sediments, has been identified in almost every sample analyzed in the upper $20 \mathrm{~m}$ of Holes $842 \mathrm{~A}$ and $842 \mathrm{~B}$ (Table 1). Ti/Al atomic ratios for Unit 1 sediments average 0.102 indicating a strong tholeiitic basalt component throughout the section (data from DeCarlo, this volume). A possible explanation for this dispersed volcanogenic material is sediment mixing by bioturbation, which would vertically redistribute volcanogenic debris delivered to the site by turbidite flow. However, this mixing is incompatible with the observed restriction of reworked fauna to intervals rich in volcanogenic debris. A relatively continuous source of airborne volcanogenic debris could also have provided the dispersed volcanogenic detritus. Donnelly $(1973,1975,1976)$ quantified the long-term accumulation of disseminated volcanic ash in both Pacific and Caribbean sites located downwind of volcanic centers. By avoiding identifiable ash layers in DSDP cores, Donnelly was able to establish that there was a background component of volcanogenic sedimentation that waxed and waned with activity at the source, or with movement of the site relative to the source owing to plate motion. The same situation probably controls background levels of volcanogenic products at Site 842 because it is located directly downwind of the Hawaiian Islands chain.

The evidence for volcanic input in Unit 2 sediments is indirect because volcanogenic grains are much less abundant than in Unit 1 . No volcanic glass was found, and percentages of plagioclase and augite drop sharply below the Unit 1/Unit 2 boundary (Figs. $2 \mathrm{C}$ and 2D). The $\mathrm{Ti} / \mathrm{Al}$ atomic ratios of Unit 2 sediments are uniformly lower as well, averaging 0.027 (data from DeCarlo, this volume). However, at depths greater than 26 mbsf in Unit 2, indurated layers are present that are similar in appearance to the altered ash layers of Unit 1. Thin laminae, mottles, and blebs of yellowish brown material are also common. Smectite and zeolite concentrations increase substantially in abundance in Unit 2 sediments, especially below 25 mbsf (Figs. $2 \mathrm{E}, 2 \mathrm{~F}$, and 3 ), and the smectite has relatively few illite interlayers. These characteristics are thought to reflect at least partial formation by alteration of volcanogenic material (Hein et al., 1976; Hein and Scholl, 1978; Vallier and Kidd, 1977). The low Ti/Al ratios of Unit 2 sediments are consistent with average shale or volcanics of andesitic or rhyolitic, but not basaltic, composition. This suggests a continental source for the volcanogenic material, perhaps from Central America.

Increased proximity to the Hawaiian Islands as a result of plate movement is reflected in the major increases in percentages of the volcanogenic grains augite (Fig. 2D) and plagioclase (Fig. 2C) and in the sharp shift to a Ti/Al ratio typical of tholeiite at the base of Unit 1 . Part of the increase in plagioclase may be due to intensified eolian deposition as discussed previously for quartz and illite, but the extremely high plagioclase content of several of the volcanogenic silt/sand layers supports significant volcanogenic input.

Diagenesis has altered the original detrital composition of the Site 842 sediments. Unstable sediment components such as biogenic silica and volcanic glass have undergone dissolution at relatively shallow depths $(<10 \mathrm{mbsf})$. The increases in abundance and crystallinity of smectite with depth (Figs. 3 and 4) suggest authigenic formation of this phase, most likely as an alteration product of volcanic glass or other volcanogenic material. The zeolites phillipsite and clinoptilolite are also likely products of the alteration reactions. Basaltic glass is a common precursor for phillipsite, and is thought to have been plentiful throughout Unit 1 . There is no evidence, however, for basaltic volcanics in Unit 2, requiring an alternative precursor (perhaps more silicic volcanics) for phillipsite in the Unit 2 sediments. Identification of precursors of clinoptilolite is not as straightforward, but glass, both basaltic and silicic, and biogenic silica are possibilities (Kastner and Stonecipher, 1978). Although only phillipsite is present in Unit 1 sediments, the stratigraphic ranges of the two zeolites overlap in Unit 2 (Figs. 2E and 2F). It is possible that the increase in dissolved silica in pore waters below a depth of $20 \mathrm{mbsf}$ (DeCarlo, this volume) favors the formation of clinoptilolite. Another authigenic phase, opal-CT, first appears at a depth of 32 mbsf in Sample 136-842B-4H$5,35-37 \mathrm{~cm}$, and comprises a substantial fraction of the bulk sediment in all the samples analyzed from Sections 136-842B-4H-6 through $-4 \mathrm{H}-8$ and Cores 136-842B-5H through $-8 \mathrm{X}$ (Table 1). The source of silica for formation of opal-CT is most likely biogenic silica.

\section{CONCLUSIONS}

The mineralogy of the Hawaiian Arch sediments sampled at Site 842 is dominated by a mixture of clay minerals, fine-grained quartz and plagioclase, and biogenic silica. This composition is similar to that of pelagic clays sampled elsewhere in the North Pacific (Schoonmaker et al., 1985). The impact of eolian deposition is evident in the increased amounts of illite and quartz both for the last 2.5 m.y. and during parts of the Miocene.

In addition to the detrital and authigenic components typically found in pelagic clay, volcanogenic detritus derived from the Hawaiian Islands is present both as discrete layers and as finely disseminated silt- and clay-sized debris. The sharp percentage change of augite and plagioclase at the lithologic Unit $1 /$ Unit 2 boundary reflects an increase in the flux of volcanic material to the site. This change is due to the approach of the site to the archipelago via plate movement, or to the onset of volcanic activity of sufficient magnitude to impact the site. The sharpness of the change, especially in the percentage of augite, suggests the possibility of loss of section. The dramatic 
increase with depth in authigenic smectite and zeolites, and the presence of indurated layers, imply that although glass is not currently present in Unit 2, volcanogenic material was originally deposited with the Unit 2 sediments. Continental volcanism is a possible source of these older volcanic materials.

Diagenetic reactions in the Site 842 sediments resulted in significant changes in the nature and distribution of porosity and in the physical structure of the matrix. Despite these changes, and the strong depth gradients in some mineral abundances, correlations between physical and acoustic properties and mineralogy are surprisingly weak or nonexistent. At the shallow depths of the samples analyzed here ( $<40 \mathrm{mbsf})$, water content appears to dominate the physical character and response of the sediment.

\section{ACKNOWLEDGMENTS}

This research was funded by the United States Science Advisory Committee and the National Science Foundation (OCE-9012145). Reviews by J. Hein, J. Firth, and an anonymous reviewer helped improve the manuscript. This is SOEST contribution no. 3236.

\section{REFERENCES}

Donnelly, T.W., 1973. Circum-Caribbean explosive volcanic activity: evidence from Leg 15 sediments. In Edgar, N.T., Saunders, J.B., et al., Init. Repts. DSDP, 15: Washington (U.S. Govt. Printing Office), 969-988.

, 1975. Neogene explosive volcanic activity of the western Pacific: Sites 292 and 296, DSDP Leg 31. In Karig, D.E., Ingle, J.C., Jr., et al., Init. Repts. DSDP, 31: Washington (U.S. Govt. Printing Office), 577-598.

, 1976. Tertiary explosive volcanic activity in the eastern equatorial Pacific Ocean: Sites 320 and 321, DSDP Leg 34. In Yeats, R.S., Hart, S.R., et al., Init. Repts. DSDP, 34: Washington (U.S. Govt. Printing Office), 605-609.

Heath, G.R., Burckle, L.H., et al., 1985. Init. Repts. DSDP, 86: Washington (U.S. Govt. Printing Office).

Hein, J.R., and Scholl, D.W., 1978. Diagenesis and distribution of late Cenozoic volcanic sediment in the southern Bering Sea. Geol. Soc. Am. Bull., 89:197-210.

Hein, J.R., Scholl, D.W., and Gutmacher, C.E., 1976. Neogene clay minerals of the far NW Pacific and southern Bering Sea. In Bailey, S.W. (Ed.), AIPEA Proc., 1975 Int. Clay Conf., Mexico City: Illinois (Applied Publ.), 71-80.

Janecek, T.R., 1985. Eolian sedimentation in the Northwest Pacific Ocean: a preliminary examination of the data from Deep Sea Drilling Project Sites
576 and 578. In Heath, G.R., Burckle, L.H., et al., Init. Repts. DSDP, 86: Washington (U.S. Govt. Printing Office), 589-603.

Kastner, M., and Stonecipher, S.A., 1978. Zeolites in pelagic sediments of the Atlantic, Pacific, and Indian oceans. In Sand, L.B., and Mumpton, F.A. (Eds.), Natural Zeolites: Occurrence, Properties, Use: New York (Pergamon Press), 199-218.

Leinen, M., 1985. Quartz content of Northwest Pacific Hole 576A and implications for Cenozoic eolian transport. In Heath, G.R., Burckle, L.H., et al., Init. Repts. DSDP, 86: Washington (U.S. Govt. Printing Office), 581-588.

Leinen, M., and Heath, G.R., 1981. Sedimentary indicators of atmospheric circulation in the Northern Hemisphere during the Cenozoic. Palaeogeogr., Palaeoclimatol., Palaeoecol., 36:1-21.

Mann, U., and Müller, G., 1979. X-ray mineralogy of Deep Sea Drilling Project Legs 51 through 53, Western North Atlantic. In Donnelly, T., Francheteau, J., Bryan, W., Robinson, P., Flower, M., Salisbury, M., et al., Init. Repts. DSDP, 51, 52, 53 (Pt. 2): Washington (U.S. Govt. Printing Office), 721-729.

Moore, D., and Reynolds, R., 1989. X-Ray Diffraction and the Identification and Analysis of Clay Minerals: New York (Oxford Univ. Press).

Schoonmaker, J., Mackenzie, F.T., Manghnani, M., Schneider, R.C., Kim, D., Weiner, A., and To, J., 1985. Mineralogy and diagenesis: their effect on acoustic and electrical properties of pelagic clays, Deep Sea Drilling Project Leg 86. In Heath, G.R., Burckle, L.H., et al., Init. Repts. DSDP, 86: Washington (U.S. Govt. Printing Office), 549-570.

Shipboard Scientific Party, 1992. Site 842. In Dziewonski, A., Wilkens, R., Firth, J., et al., Proc. ODP, Init. Repts., 136: College Station, TX (Ocean Drilling Program), 37-63.

Underwood, M., Orr, R., Pickering, K., and Taira, A., 1993. Provenance and dispersal patterns of sediments in the turbidite wedge of Nankai Trough. In Hill, I.A., Taira, A., Firth, J.V., et al., Proc. ODP, Sci. Results, 131: College Station, TX (Ocean Drilling Program), 15-34.

Vallier, T.L., and Kidd, R.B., 1977. Volcanogenic sediments in the Indian Ocean. In Heirtzler, J.R. (Ed.), Indian Ocean Geology and Biostratigraphy. Am. Geophys. Union, 87-118.

Winterer, E.L., Riedel, W.R., et al., 1971. Init. Repts. DSDP, 7: Washington (U.S. Govt. Printing Office).

\footnotetext{
-Abbreviations for names of organizations and publications in ODP reference lists follow the style given in Chemical Abstracts Service Source Index (published by American Chemical Society).
}

Date of initial receipt: 7 December 1992

Date of acceptance: 13 April 1993

Ms 136SR-205

Ms 136SR-205 


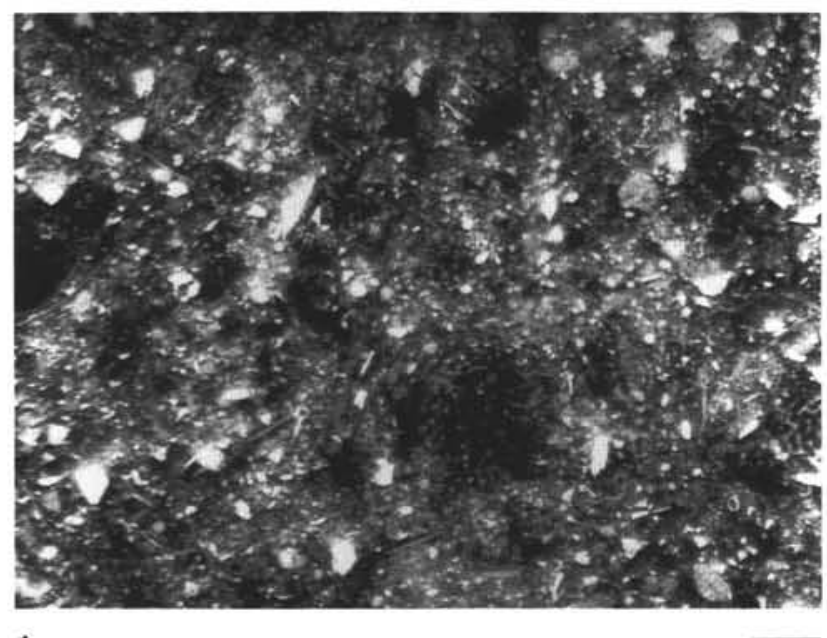

1

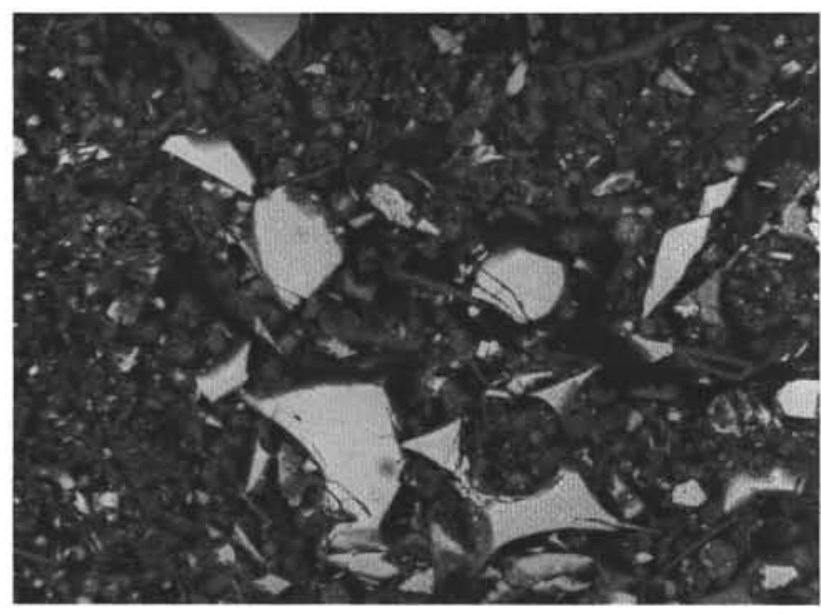

3
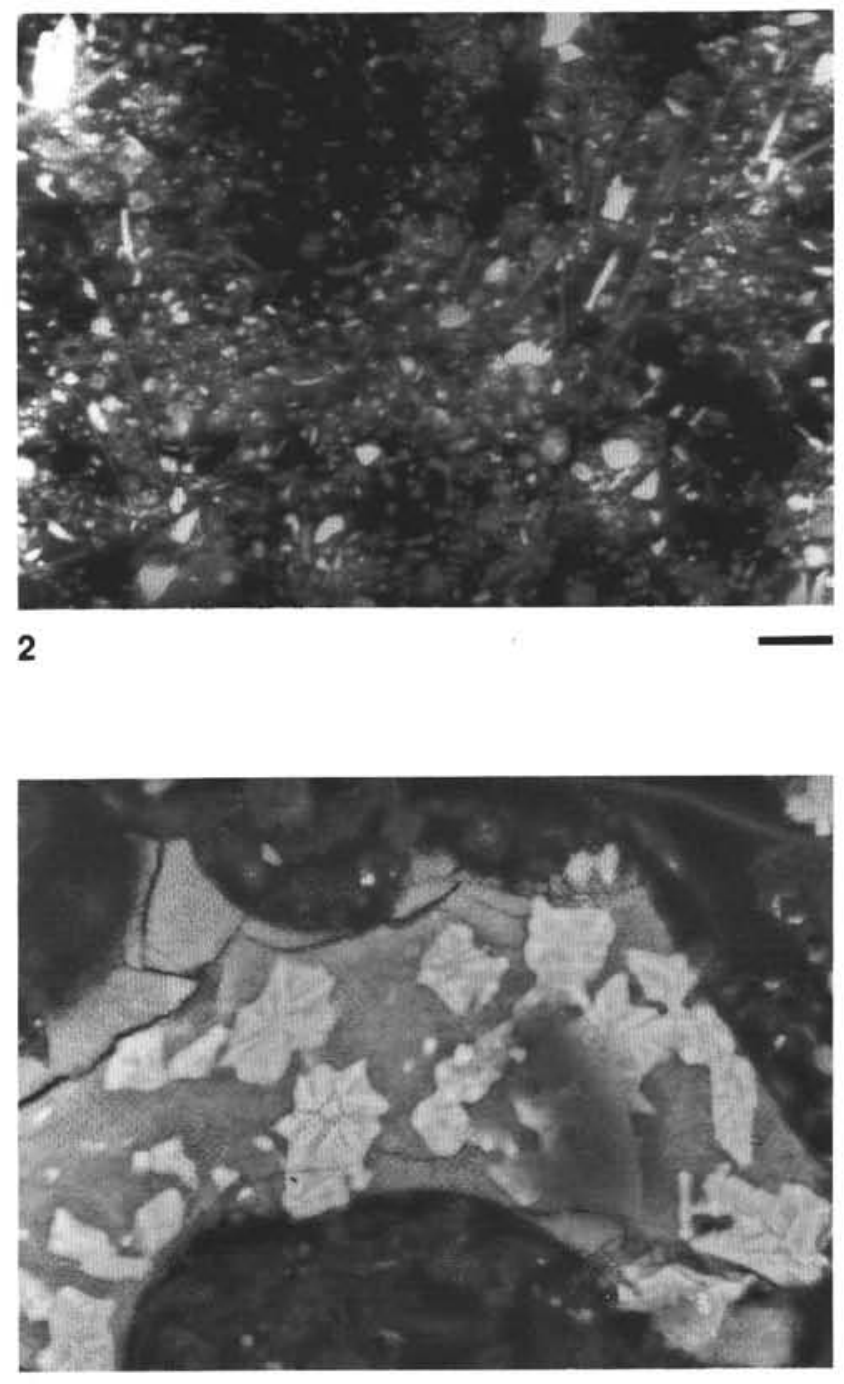

4

Plate 1. BSEI photomicrographs of sediments from Site 842. 1. Sample 136-842B-1H-1, 144-145 cm (1.44 mbsf), showing high porosity and floc-like nature of the clay mineral matrix. Scale bar $=50 \mu \mathrm{m}$. 2. Enlargement of (1). Scale bar $=20 \mu \mathrm{m}$. 3. Typical pristine volcanic glass shards from Sample 136-842A-1H-2, 143-145 cm (2.93 mbsf). Scale bar $=20 \mu \mathrm{m}$. 4. Glass shard from same sample showing features indicative of incipient crystallization. The edges of this type of glass commonly show evidence of initial stages of alteration. Scale bar $=7.5 \mu \mathrm{m}$. 


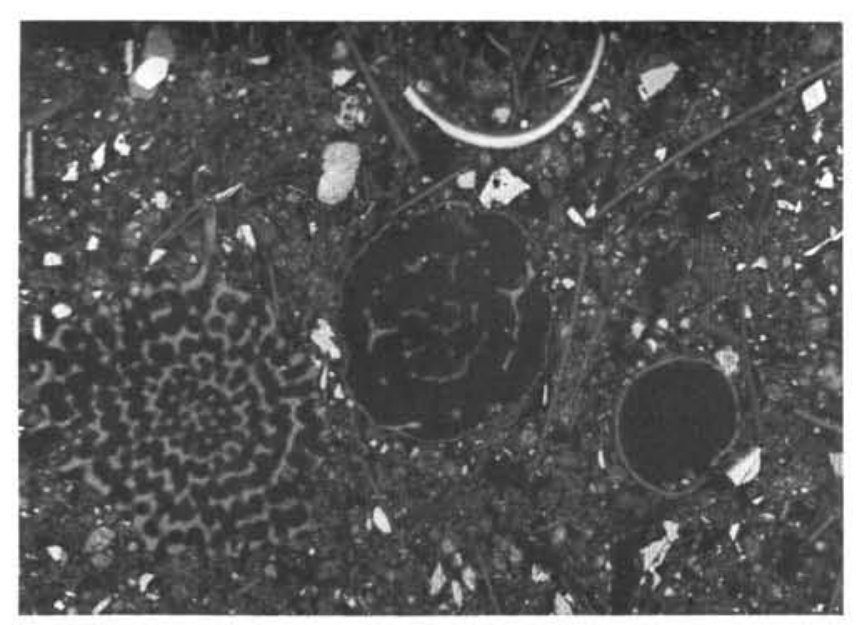

1

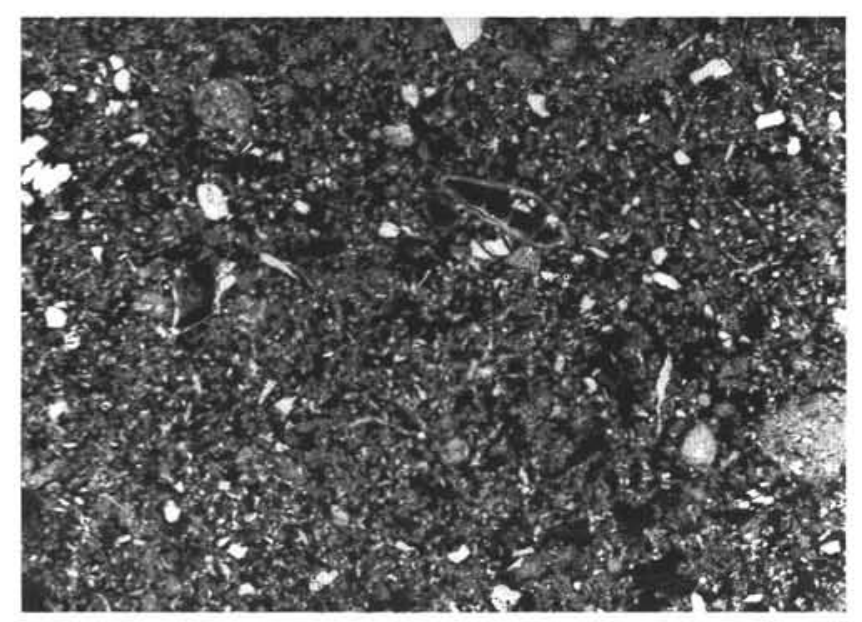

3

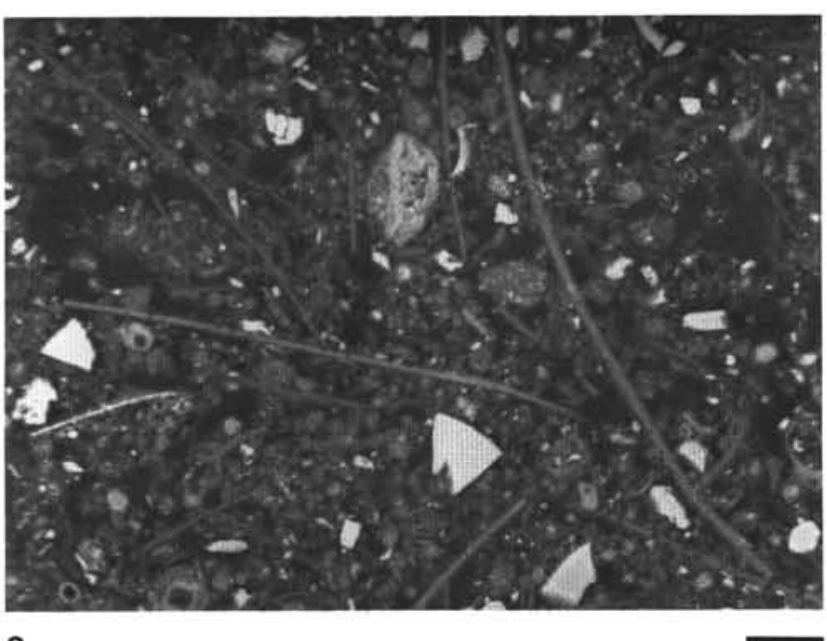

2

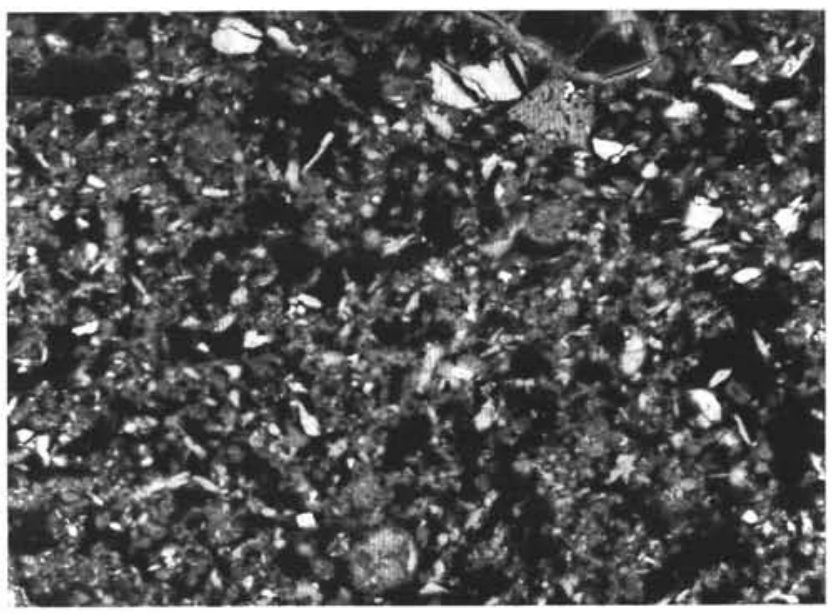

4

Plate 2. BSEI photomicrographs of sediments from Site 842. 1. Sample $136-842 \mathrm{~A}-1 \mathrm{H}-5,143-145 \mathrm{~cm}(7.43 \mathrm{mbsf})$. Several radiolarians in differing states of dissolution are shown. Dissolution of the tests leaves large pore spaces. Scale bar $=20 \mu \mathrm{m}$. 2. Diatom spines from the same sample show no signs of dissolution. Scale bar $=20 \mu \mathrm{m}$. 3. Sample 136-842B-2H-4, 5-6 cm (10.85 mbsf), showing matrix microfabric typical of intermediate burial depths. Matrix clay minerals form an interlocking network that maintains high porosities. Scale bar $=50 \mu \mathrm{m}$. 4. Enlargement of (3). Scale bar $=20 \mu \mathrm{m}$. 


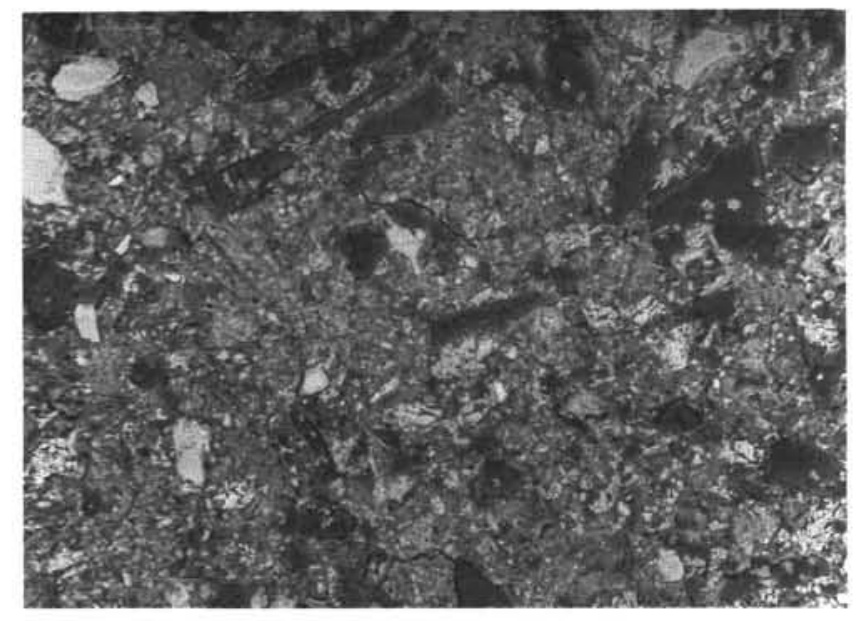

1

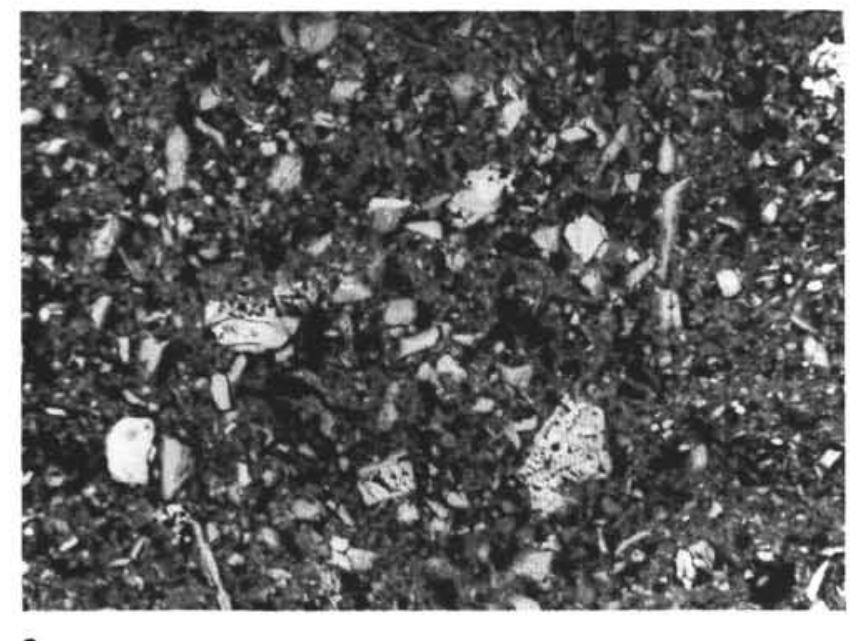

3

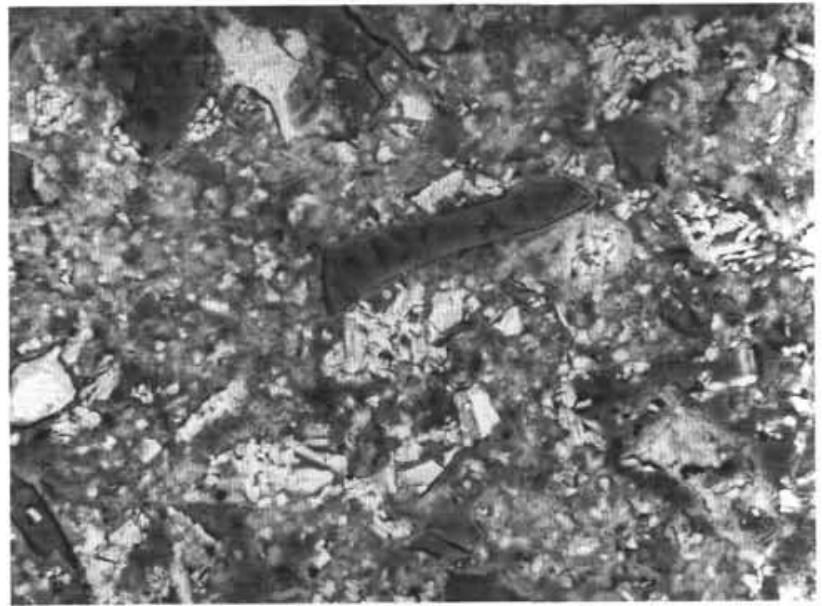

2

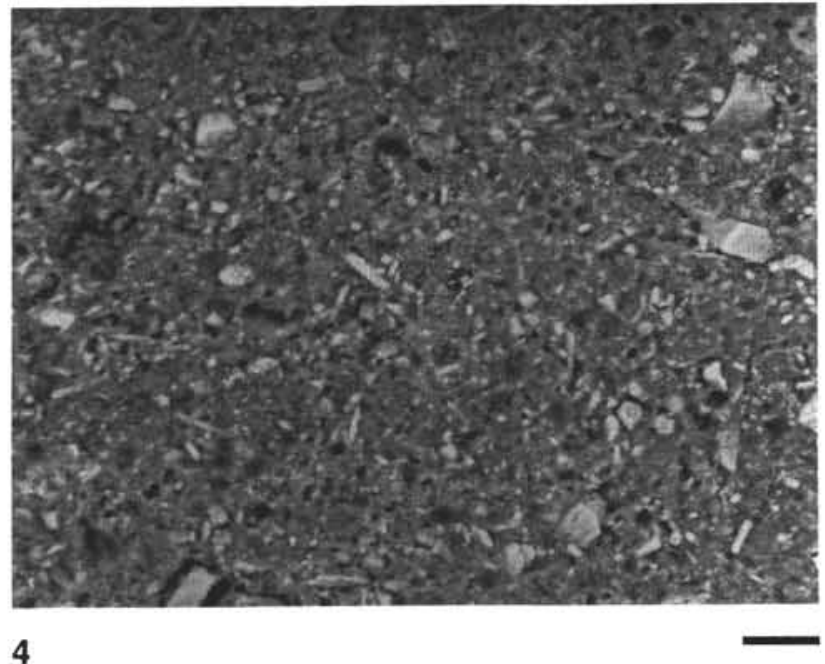

Plate 3. BSEI photomicrographs of sediments from Site 842. 1. A volcanic-rich layer (Sample 136-842B-2H-5, 142-144 cm; $13.72 \mathrm{mbsf}$ ). Dissolution of mineral grains has left voids in the dense clay mineral and zeolite matrix. Scale bar $=50 \mu \mathrm{m}$. 2. Enlargement of $(1)$. Scale bar $=20 \mu \mathrm{m}$. 3 . Sample 136-842B-3H-2, 143-145 cm (18.73 mbsf). The interlocking network of clay domains is still evident, although porosity is reduced. Scale bar $=20 \mu \mathrm{m}$. 4. Sample 136-842B-3H-6, 108-110 cm (24.38 mbsf). The clay matrix is densely packed and the network of clay domains typical of shallower samples is no longer apparent. Scale bar $=20 \mu \mathrm{m}$. 


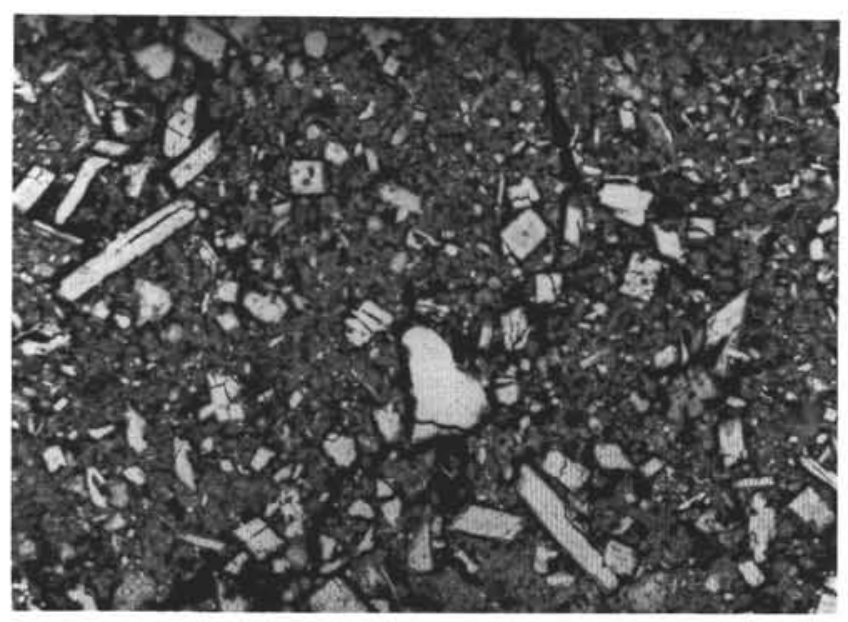

1

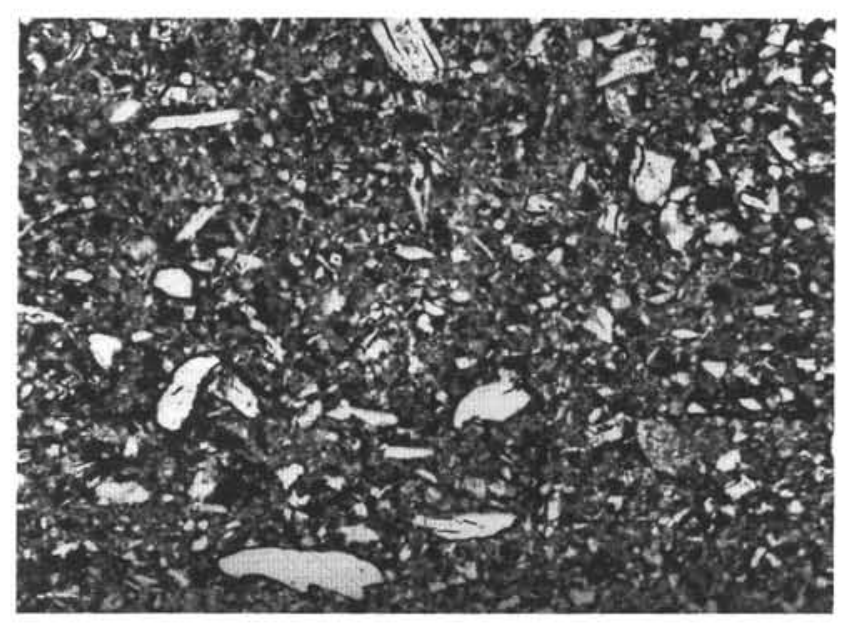

2

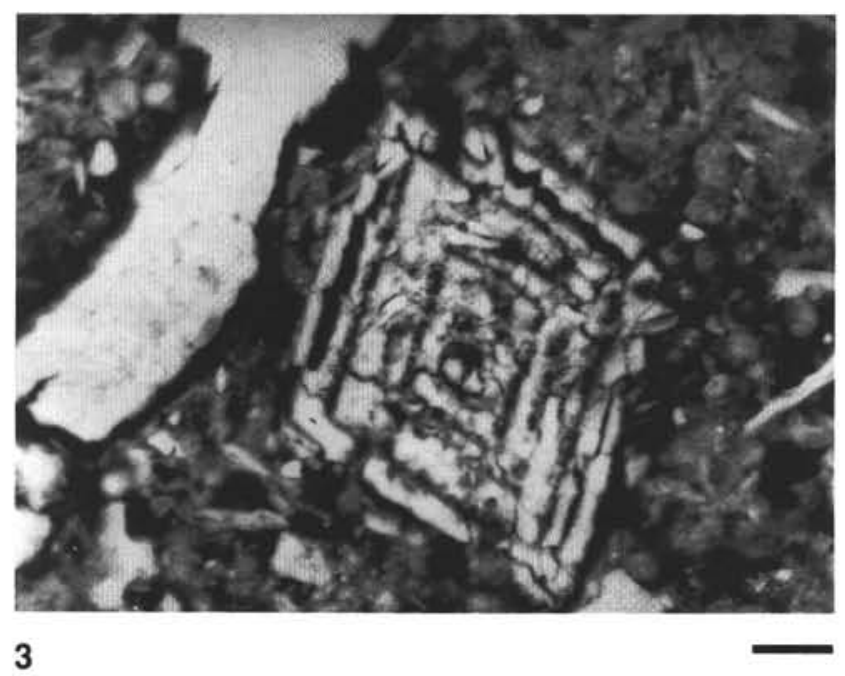

Plate 4. BSEl photomicrographs of Site 842 sediment. 1. Zeolite rich sediment (Sample 136-842B-4H-2, $143-145 \mathrm{~cm} ; 28.23 \mathrm{mbsf}$ ). Scale bar $=20 \mu \mathrm{m}$. 2. Sample 136-842B-4H-4, 104-106 cm (30.84 mbsf). Zeolites are smaller and less abundant than in sample shown in (1). Scale bar $=20 \mu \mathrm{m}$. 3. Same sample as in (2). Large $(\sim 35 \mu \mathrm{m})$ grain of phillipsite undergoing preferential dissolution along cleavage planes. Large bright grain in upper left corner is apatite. Scale bar $=7.5 \mu \mathrm{m}$. 